\title{
Jesus healing the leper and the Purity Law in the Gospel of Matthew
}

\author{
Author: \\ Francois P. Viljoen ${ }^{1}$ \\ Affiliation: \\ ${ }^{1}$ Faculty of Theology, \\ North-West University, \\ Potchefstroom Campus, \\ South Africa \\ Correspondence to: \\ Francois Viljoen \\ Email: \\ viljoen.francois@nwu.ac.za \\ Postal address: \\ Private Bag X6001, \\ Potchefstroom 2520, \\ South Africa \\ Dates: \\ Received: 09 Sept. 2013 \\ Accepted: 30 Jan. 2014 \\ Published: 20 May 2014 \\ How to cite this article: \\ Viljoen, F.P., 2014, 'Jesus \\ healing the leper and the \\ Purity Law in the Gospel \\ of Matthew', In die Skriflig \\ 48(2), Art. \#1751, 7 pages. \\ http://dx.doi.org/10.4102/ \\ ids.v48i2.1751

\section{Copyright:} \\ (C) 2014. The Authors. \\ Licensee: AOSIS \\ OpenJournals. This work \\ is licensed under the \\ Creative Commons \\ Attribution License.
}

Read online:
Though, in the Sermon on the Mount, Jesus explicitly states that he did not come to abolish the Law (Mt 5:17-19), in the narrative that follows directly after this Sermon, he apparently neglects purity laws by healing a leper (Mt 8:1-3). As an impure person, the leper was not supposed to come close to Jesus, but Jesus sympathetically reaches out and touches him. Furthermore, no mention is made of Jesus undergoing any purification rites after coming into contact with this man. Once the leper is healed, Jesus instructs him to perform only the third phase of the prescribed purification rite for lepers. Jesus is thus described as having the power and authority to heal the person and to declare him healed. What remains for the leper is to show himself to the priest and to bring the appropriate sacrifice, so that he could be accepted into the society again. In this article it is argued that Jesus, as the Holy One and miracle Healer, is not defiled by coming into contact with the leper. Purity flows from Jesus to heal the leper. As a teacher of the Law, Jesus enacts the true intention of the Law, which is to establish a holy community of believers within the Kingdom of heaven. This healing action forms a step towards the coming of the Kingdom of heaven. Thus, the purity laws find their fulfilment in Jesus. As result of this action, cultic purity transforms into a moral activity for the followers of Jesus.

Jesus se genesing van die melaatse en die reinheidswet in Matteus. Hoewel Jesus in die Bergrede eksplisiet noem dat Hy nie gekom het om die Wet ongeldig te maak nie (Matt 5:15-19), lyk dit asof $\mathrm{Hy}$, in die vertelling wat direk op die Rede volg, die reinheidswette oortree het deur die manier waarop Hy 'n melaatse genees (Matt 8:1-3). As 'n onrein persoon was die melaatste nie veronderstel om naby Jesus te kom nie, maar Jesus het simpatiek na hom toe uitgereik en hom aangeraak. Hierbenewens word geen melding daarvan gemaak dat Jesus enige reinigingsrituele ondergaan het nadat hy in kontak met hierdie man was nie. Nadat die melaatse genees is, beveel Jesus hom om slegs die derde fase van die voorgeskrewe reinigingsrituele vir melaatses uit te voer. Jesus word sodoende beskryf as iemand wat die mag en gesag het om 'n persoon te genees en gesond te verklaar. Wat oorbly, is dat die melaatse homself aan die priester moet gaan wys en die gepaste offer bring, sodat hy weer in die gemeenskap opgeneem kan word. Hierdie artikel argumenteer dat Jesus, as heilige persoon en wondergeneser, nie onrein word wanneer Hy in kontak met die melaatse kom nie. Reinheid vloei vanaf Jesus oor na die melaatse. As leraar van die Wet beoefen Jesus die ware bedoeling van die Wet, wat ten doel het om die heilige gemeenskap van gelowiges in die Koninkryk van die hemel te vestig. Hierdie genesingsaksie is nog ' $n$ tree in die koms van die Koninkryk van die hemel. Sodoende vind die reinheidswette hulle vervulling in Jesus. As gevolg hiervan verander kultiese reinheid na morele optrede vir die navolgers van Jesus.

\section{Introduction}

It seems that Matthew's Jesus is not concerned with becoming impure or pure again after contracting impurity (Deines 2008:65). Matthew does not mention any purification rites in connection with Jesus and the disciples - not even before entering the temple. He only describes Jesus taking actions that seemingly contravene purity regulations found in the Hebrew Bible. These include regulations such as refraining from contact with persons with skin diseases ( $\mathrm{Lv}$ 13-14; Nm 5:2), but Jesus touches a leper (Mt 8:3), or avoiding contact with women with abnormal menstrual discharge (Lv 25-30), but Jesus does not object when such a woman touches him (Mt 9:20-22), or avoiding contact with a dead body (Nm 5:2; 19:11-13) or entering the room of a dead person (Nm 19:14), but Jesus enters the room of a dead girl and touches her (Mt 9:25). In cases where such contact occurs accidentally or is necessary, the Hebrew Bible prescribes that the defiled person has to undergo specific purification rites (Nm 19). The neglect of such purification

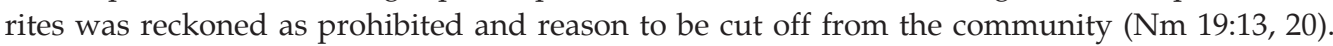
Matthew, however, makes no mention of Jesus undergoing such purification rites. Considering 
Matthew's readers were mostly Jewish Christians, hearing of Jesus' apparent negligence would immediately have been reason for concern. Matthew also tells the story where Jesus criticises the tradition of the Pharisees about washing their hands before meals (Mt 15:10, 16-20). Furthermore, in the woe-sayings of Matthew 23, Jesus criticises the practice of cleaning utensils for eating whilst the people who eat are dirty within (Mt 23:25-27), referring to the condition of their hearts. Israelites, particularly during the First ${ }^{1}$ and Second ${ }^{2}$ Temple period, normally observed the laws of purity (taharah) and impurity $\left(\right.$ tum $\left.^{\prime} a\right)$, as their identity was strongly defined by these laws (Hayes 2007:750; Westerholm 1992:127-131). The Jews definitely must have found Jesus' attitude towards purity regulations disturbing.

In this article, one of Jesus' apparent provocative actions against the Jewish purity regulations is investigated, namely that of Jesus touching a leper (Mt 8:3). ${ }^{3}$ Though Jesus emphasises that he did not come to abolish the $\mathrm{Law}^{4}$ (Mt 5:17-19), he clearly demonstrates an alternative interpretation of the Purity Law. The intention of this article is to establish what light the story of Jesus healing the leper could cast on Jesus' relation to and interpretation of the Law. To do this, the article first investigates Jewish purity regulations with regard to leprosy and purification rites, followed by the textual context in Matthew of Jesus as teacher of the Law. Jesus' healing of the leper will then be evaluated in the light of the Jewish purity laws and social values of those times. This comparison finally culminates in certain conclusions related to the identity of Matthew's community.

\section{Purity and leprosy in the Hebrew Bible}

Purity can be described as the condition that God requires of his people. Only those who are pure may come in contact with him. In the Hebrew Bible purity is linked with the requirement of righteousness (Chilton 2000:877). The psalms explicitly state this association. ${ }^{5}$ Only the one who has clean hands and a pure heart may ascend the mountain of the Lord and stand in his holy place (Ps 24:3-4; cf. Ps 18:21; 26:4-7; $51: 4,8,9,12 ; 119: 9)$.

Impurity results from coming into contact with anything that assumingly should not exist, for example a corpse or what

1.The first temple was constructed by Solomon in ca. $832 \mathrm{BCE}$ and destroyed by the Babylonians under Nebuchadnezzar II in ca. 586 BCE (Grintz 2007; Eisen 2004:54).

2.The Second Temple period lasted between ca. 530 BCE and 70 CE. The Second Temple period ended with the First Jewish-Roman War and the Roman destruction of Jerusalem and the temple (Avi-Yonah 2007).

3.Other examples include where Jesus does not resist when a woman with blood flow touches him (Mt 9:20-22) and where Jesus enters a room of a dead girl and touches her (Mt 9:25). These wil be discussed in a future article. Jesus' arguments on purity in Matthew 15 and 23 are also significant in relation to the issue of purity, and the intention is to attend to these arguments in yet another article, with special attention to the applicable dietary laws.

4. The Hebrew term for the Law, Torah, included written and oral regulations of the Israelites and Jews. In a more restricted sense, it referred to the Law of Moses the Pentateuch. The Pentateuch includes a whole range of instructions about loyalty, morality and purity. Whilst the Sadducees only held to the written Law of Moses (Pentateuch), the Pharisees also accepted the Prophets and the Writings as authoritative. Furthermore, they regarded the oral traditions of 'their fathers'.

5. This link between purity and morality is significant, as it becomes a hermeneutical key to Jesus' interpretation of purity regulations. was considered a monstrous beast (Chilton 2000:874). The priestly writings of the Hebrew Bible, especially the Holiness Code (Lv 17-26), present a systematic legislation on the topic of purity and impurity. A person or object can become tame [ritually impure] in several ways, including sexual immorality $(\mathrm{Lv} 18,20)$, rules of diet (Lv 11) and touching unclean objects or beings (e.g. Nm 19:22; Westerholm 1992:125-127; Wright 1992b:730-736). In the Jewish communities in the Second Temple period, the concept of purity functioned as an identity marker and was regarded as an absolute binding inheritance from early Judaism. This issue was directly related to the authority of the Mosaic Law (Hübner 1992:741). Biblical laws on purity have been extended in rabbinic halakhah, as at least one third of the Mishnah ${ }^{6}$ deals with ritual purity (Hayes 2007:750). The importance of purity regulations is particularly evident in the writings of Qumran, with their strong emphasis on purity in their Purity Texts (4Q274-279; Q281-284; Q512-514). In these texts, laws are recorded that were promulgated to clarify and supplement the Mosaic code (cf. Bowley 2000). The identity of their community was based on purity laws (Hübner ibid:742).

Leviticus 17-26 describe a broad spectrum of impurities: from those that are harmless and last for one day only, up to those that are extremely severe (Hayes 2007:746; Wright 1992b:736-738). In this article, the focus is limited to the issue of leprosy and the purification rites related to it.

\section{Leprosy and impurity}

Leprosy (tsara'at) was regarded as an impurity (Lv 13-14; Nm 5:2). Modern discussions on leprosy focus on the distinction between the disease caused by Hansen's Bacillus and superficially similar diseases. In the Bible, 'leprosy' is used to describe a variety of skin diseases of varying severity (Hayes 2007:747; Wright \& Jones 1992:277), so that the translation of tsara'at as 'leprosy' for today's context might not always be accurate. 'Leprosy' was used to describe all kinds of repulsive scaly and flaky conditions that affected people, clothing and houses (Pilch 1981).

Leprosy was highly dreaded in the ancient world. It was regarded a terrible and defiling disease, as those who were infected were physically and ceremonially regarded as unclean (Hagner 1993:198; Morris 1992:189; Talbert 2010:112; Wright \& Jones 1992:281). In the Hebrew Bible, leprosy was usually viewed as God's punishment for sinful behaviour (cf. 2 Ki 5; 2 Chr 26:16-21; Nm 12:10-15). Leprosy was associated with death and people perceived it as a living death (Nm 12:12; Job 18:13). The notion that lepers were living dead is reflected in several texts (e.g. Nm 12:12; $2 \mathrm{Ki}$ 5:7; Job 18:13; Davies \& Allison 2004b:11). According to the rabbis, it was so difficult to heal leprosy that they compared such healing with raising a person from the dead (Luz 2001:5; Marshall 1978:208; Witherington 2006:178).

6.The Mishnah consists of six orders (sedarim), each containing 7-12 tractates (masechtot). The sixth order is the longest of the orders, comprising 12 tractates. (masechtot). The sixth order is the longest of the orders, comprising 12 tractates.
These tractates deal with tehorot [purities] pertaining to the laws of purity and impurity, including the impurity of the dead, the laws of food purity and bodily purity. 
Leprosy was associated with uncleanness and a great social stigma was attached to it (Ellingworth 1992:463; Pilch 1981). It was a socially devalued condition with serious social consequences. People diagnosed with or suspected of leprosy were excluded from the community ( $\operatorname{Lv} 13: 45-46$, Nm 5:2-3). Contact with lepers had to be avoided and lepers had to warn others not to come close to them ( $\operatorname{Lv} 13: 45)$.

Pharisees were equally concerned about avoiding lepers, as an entire tractate of the Mishnah, the Nega'im [blemishes], is devoted to this issue (Chilton 2000:877). Lepers were regarded as impure and unholy. This unholy condition was seen to violate God's will: 'You shall be holy because I am holy' (Lv 11:44-45). The community was concerned about pollution, rather than contagion, when coming into contact with lepers (Pilch \& Malina 1998:104). Leprosy was regarded as highly symbolic within the sphere of death (Senior 1998:97). As living dead, they were regarded as being under God's judgement (Hagner 1993:198). Josephus confirms in his writings ( 37 to ca. 100 AD) that this was still the situation that lepers had to endure in the time of Jesus. Josephus wrote: 'Anyone who touches or lives under the same roof [with a leper] is regarded unclean' (Contra Apionem 1.281) and that such people were kept away from normal society (Antiquitates Judaicae 9:74). 'As an attack on the skin $[\ldots]$ leprosy threatens or attacks [...] integrity, wholeness and completeness of the community and its members' (Carter 2000:199; cf. Pilch 1981:113). Roth (1994:108-109) points out that no command existed to take care of lepers. Lepers had to form their own colonies separate from the healthy communities and survive on their own ( $\mathrm{Lv} 13: 45$; Davies \& Allison 2004b:11; Morris 1992:188).

The Hebrew Bible reports two occasions where lepers are healed: Miriam's seven-day leprosy (Nm 12) and Elisha's healing of Naaman (2 Ki 5:1-15). This second story is of particular interest, as it describes the ability to heal a leper as the sign of a prophet (2 Ki 5:8). As the rabbis regarded the cure of a leper as difficult as raising a person from the dead, the supernatural healing of lepers was expected as one of the signs of the messianic age ${ }^{8}$ (Ellingworth 1992:463; Hagner 1993:198). At the beginning of the series of healing stories in Mt $8-9,{ }^{9}$ the story of the healing of the leper thus presents Jesus as the messianic prophet (Davies \& Allison 2004b:11).

\section{Purification rites}

Extensive purification rites were prescribed for persons who recovered from 'leprosy'. It consisted of three phases (Wright \& Jones 1992:280-281). For the first phase, bird blood and water had to be sprinkled on such a person and a live bird

7.The Nega'im consists of 14 chapters. This tractate describes the various forms of leprosy that affected people, clothing and homes. It describes the different symptoms of the disease and the various rituals involved in purifying someone who has been affected.

8.It is due to this expectation that Jesus inter alia replied to the enquiry of John the Baptist: 'Are you the one who was to come, or should we expect someone else?' that 'those who have leprosy are cured' (Mt 11:3-4).

9.Matthew sets out a distinctive arrangement of the series of miracle stories parallel to those reported in Mark. He makes the dramatic healing of the leper the firs miracle, whilst Mark (Mk 1:40-45) describes it as the last miracle of the first day of healing in Capernaum (Senior 1998:95). sent away to remove the impurity from the person (Lv 14:2-7). During the second phase the person had to bath, launder and shave at the beginning and end of a seven-day quarantine period ( $\operatorname{Lv} 14: 8-9$ ). During the third phase the person had to bring sacrifices (Lv 14:10-32) and blood and oil were placed on the ear, thumb and toe of the healed person ( $\operatorname{Lv} 8: 22-30)$. Once this had been done, the person could be assimilated into the community again.

The impurity resulting from contact with a contaminated person also had to be dealt with (Wright 1992b:737-738). A person who helped to purify a person or house that has recovered from leprosy was regarded as polluted and had to launder and bath (Lv 14:2-7, 49-53). However, if pollution could have been avoided or purification was delayed, such action was considered as sinful and required additional ablution (Lv 5:2-3). Persons who advertently did not purify themselves would suffer being karet [cut off], or expelled and extirpated (Lv 18:24-30; Nm 19:13, 20; Chilton 2000:874; Hayes 2007:749).

\section{The impurity of leprosy and the religious space}

As leprosy was associated with death (Nm 12:12; Job 18:13), it was considered impure. Impurity threatens what is holy (Wright 1992a:237). Purity is related to holiness and impurity to profaneness (Lv 10:10). God, the 'Holy One of Israel' (Is $1: 4 ; 5: 19,24)$, is the ideal manifestation and source of holiness. As God is holy, he requires of his people to be holy too - as is echoed with the refrain: 'You are to be holy to me because I, the Lord, am holy' (Lv 11:44-45; 19:2; 20:7-8, 24-26; 22:32-33).

The spaces in which God's people operate should reflect their holiness. The symbolic space for the religious community is demonstrated in Figure 1.

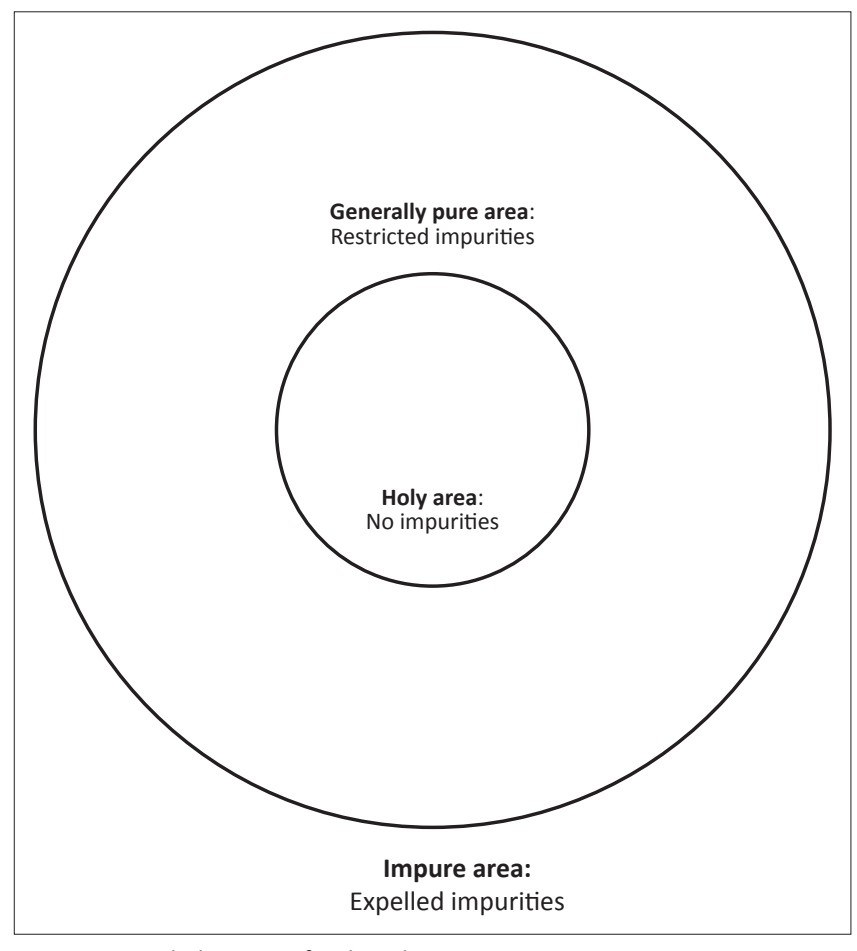

FIGURE 1: Symbolic spaces for the religious community. 
The religious community has two spheres: the generally pure area and the holy area. Within the holy area, no impurity is permitted. The religious community lives within the generally pure area. Some impurities can be rectified within this sphere by way of proper adherence to specified purification rituals. Otherwise, such impurity must be cut out of the community (referring to the practice of karet) and be expelled to the impure area. If impurity such as leprosy, threatens to pollute the generally pure community, it should be removed from the community (Wright \& Jones 1992:281). Lepers therefore had to abide outside the borders of the generally pure area.

\section{Jesus and purity in Matthew}

In the Matthean Gospel it seems as if Jesus, on several occasions, ${ }^{10}$ does not observe these laws of purity. Jewish religious leaders found this conduct by Jesus offensive and objectionable. In the narrative, this theme leads to Jesus' dispute with Pharisees and scribes on purity regulations (Mt 15:20), and his very harsh woe-saying against the scribes and the Pharisees on their cleaning rites (Mt 23:25-26).

The question therefore arises of how this described behaviour of Jesus correlates with his explicit statement that his mission was not to abolish the Law or prophets, but to fulfil them (Mt 5:17-19). A secondary question arises as to what the Matthean Jesus then regards as pure and impure. With his description of these actions and arguments of Jesus, Matthew obviously intended to inform his readers of an alternative interpretation and application of purity regulations, as demonstrated by Jesus. Jesus values purity highly, as he pronounces in the Beatitudes: 'Blessed are the pure in heart, for they will see God' (Mt 5:8), but he clearly means something different from what was observed by the Jews of his day. According to this beatitude, a pure heart must form part of the identity of a follower of Jesus.

When Jesus touches the leper (Mt 8:3), he apparently transgresses purity regulations. This incidence is investigated below in order to offer a proposal of how Jesus' interpretation of purity should be understood.

\section{The teacher of the Law enacts the Law}

When observing the story of Jesus' touching of the leper, it is important to consider the textual context of the Law in which this story is set.

Matthew ends his account of the Sermon on the Mount by telling that Jesus came down from the mountain, as Moses once did from Mount Sinai (Ex 19:14; 32:1; 34:29). He thus draws a parallel between Jesus and Moses, and the Mount of Jesus' sermon and Mount Sinai (Carter 2000:198; Davies \& Allison 2004b:9; Luz 2001:5). ${ }^{11}$ The impressive and authoritative teacher of the Law found in the discourse

10. When approached by a leper, Jesus does not scare away - he even touches him (Mt 8:3). He does not object when a woman with blood flow touches him (Mt 9:20), and he enters the room of a dead girl and even takes her by the hand to heal her (Mt 9:25)

11.This correlation has been demonstrated in another article (Viljoen 2013). is subsequently presented in the narrative as going into action to demonstrate how the Law should be practiced. Jesus confirms his authority by performing 10 miracles. Grundmann (1971:111) fittingly describes the Sermon on the Mount as 'das Wirken des Christus Jesus durch das Wort' ['the work of Christ Jesus through the word'] and the miracles that follow as 'das Wirken des Christus Jesus durch die Tat' ['the work of Christ Jesus through the deed'] (Grundmann ibid:245).

The discourse (Sermon on the Mount) and the narrative (10 miracle stories) are linked by two summaries of the miracles that Jesus performed (Mt 4:23-25;12 Mt 9:35 ${ }^{13}$ ) to form some sort of compositional frame around them (Morris 1992:186; Senior 1998:94; Talbert 2010:109). Both these summaries refer to the Kingdom of God. With his inaugural proclamation, 'Repent, for the Kingdom of heaven is at hand' (Mt 4:17), ${ }^{14}$ Jesus states that the future Kingdom of God is breaking into the present already (Duling 1992:57). The Kingdom does not only signify the territory where God rules, but also his activity as ruler, as envisioned in Deutero-Isaiah (Davies \& Allison 2004a:389). For Jesus the coming of the Kingdom did not comprise of one moment, but realises through a series of events over a period of time. A similar process is described in Jubilees 23 , according to which the age of blessedness enters history step-by-step. Similarly, the eschatological transition of the so-called 'Apocalypse of the Weeks' is a prolonged process (1 En 93; 91:12-17). When Jesus announces that the Kingdom of heaven has come and is coming, he indicates that the process of the realisation of God's rule has started, but the completion lies in the future, when the last things will come. The coming of the Kingdom is being established by Jesus. His teaching (Sermon on the Mount) and activity (healing miracles) realise the blessings associated with the coming of the Kingdom step-by-step.

The healing narrative describes a series of 10 miracle stories. Matthew tells a series of nine healing miracles stories (Mt 8-9) ${ }^{15}$ and a nature miracle of Jesus stilling the storm (Mt 8:23-27) - making a total of 10. As early as 1927, Klostermann (1927:72) argued that Jesus' 10 miracle stories allude to the 10 miracles of the exodus from Egypt (Ex 7-12). Some arguments can be identified in favour of Klostermann's argument. Micah prophesied that Israel and Judah would experience a new exodus from exile: 'As in the days when you came out of Egypt, I will show them

12.'Jesus went throughout Galilee, teaching in their synagogues, proclaiming the good news of the kingdom, and healing every disease and sickness amongst the people [...] and people brought to him all who were ill with various diseases, those suffering severe pain, the demon-possessed, those having seizures, and the paralyzed; and he healed them' (Mt 4:23-25).

13.'Jesus went through all the towns and villages, teaching in their synagogues, proclaiming the good news of the kingdom and healing every disease and sickness' (Mt 9:35).

14.'Kingdom of heaven' is seemingly used as equivalent of 'kingdom of God'. This periphrasis for God is probably a result of rabbinic influence to avoid the divine name. Moreover, Matthew does not only use 'kingdom of heaven' (e.g. Mt 4:17; $18: 1 ; 20: 1 ; 25: 1)$, but also 'kingdom of God' (e.g. Mt 6:33; 12:28), 'kingdom of my Father' (Mt 26:29), 'kingdom of the Son of man' (Mt 16:28) and the absolute 'the kingdom' (Mt 4:23; 9:25).

15.The nine healings are that of the leper, the centurion's servant, Peter's motherin-law, the Gaderene demoniacs, the paralysed man, the ruler's daughter, the woman with blood flow, the blind men and the dumb man. 
my wonders' (Mi 7:15). Some early Christians applied this prophesy to the ministry of Jesus:

As Moses did signs and miracles, so also did Jesus. And there is no doubt but that the likeness of the signs proves him [Jesus] to be that prophet of whom he [Moses] said that he should come 'like myself'. (Pseudo-Clementine, Recognitiones 1.57)

Jesus is regarded as the new Moses. One could critique this stance, as Jesus' acts of mercy are not directly comparable with the plagues in Egypt (Hagner 1993:195; Morris 1992:186), but one should also take into consideration that the contexts of these miracles are different. Further critique of such a correlation can be offered, as Matthew's miracle stories are presented in triads of three each (Mt 8:2-17; 8:18-9:17 and 9:18-34; Garland 2001:92; Talbert 2010:111). However, the story of the bleeding woman is sandwiched in-between that of the reawakening of the dead girl, so that there are indeed 10 miracle stories. Interesting enough, Philo also presents the plagues of Exodus 7-12 in terms of three triads (De Vita Mosis 1.97-139). Drawing a link between Moses and Jesus therefore seems to be plausible. As Moses in Exodus was involved in 10 miracles and giving of the Law, Jesus authoritatively interprets the Law (in the Sermon on the Mount) and then authoritatively performs his interpretation of the Law (in the miracle narratives).

\section{Jesus touching a leper (Mt 8:3)}

Matthew begins the healing miracles with his first triad by telling how Jesus healed people in Israel:

- The man with leprosy (Mt 8:1-4).

- The servant of the centurion (Mt 8:5-13).

- Peter's mother-in-law (Mt 8:14-16).

These three healing stories are concluded with the remark that Jesus healed many demon-possessed people (Mt 8:16) as well as a reference to Isaiah 53:4: 'He took up our infirmities and carried our diseases' (Mt 8:17; Senior 1998:96; Talbert 2010:111). Matthew alludes to the fact that Jesus should be identified with the servant of the Isaiah songs and recognised as the promised Messiah (Hagner 1993:210).

With the first of these healings, Jesus is approached by a leper with the request to be cleansed ( $\mathrm{Mt} 8: 2$ ). The leper in the story acted contrary to the instructions, stipulated in Leviticus 13-14, of how persons with such skin diseases should act. Being contagious and unclean persons, lepers were supposed to isolate themselves from others, demonstrate their impurity and warn people of their illness. They had to wear torn clothes, let their hair be unkempt, cover the lower part of their faces and shout 'Unclean! Unclean!' (tame' we-tame';

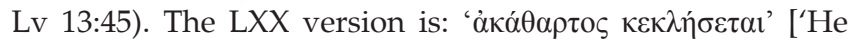
must shout: "unclean!"']. Instead of shouting 'Unclean! Unclean!', which implies 'Be warned, I am unclean and will make you unclean too', the leper in the story begs: 'Make me clean', which implies: 'You are clean and can make me

16. Matthew $26: 6$ describes Jesus staying in the house of Simon, who was affected by leprosy. He was probably a leper that has been cured (by Jesus maybe?). It is by leprosy. He was probably a leper that has been cured (by Jesus maybe?). It is \& Allison 2004a:197; Hagner 1995:757). Nevertheless, it indicates that Jesus, yet $\&$ Allison 2004a:197; Hagner 1995:757). Neverthe
again, befriended a (previously) social outcast. clean too.' This contrast highlights the social and religious implication of his illness on the one hand, but also his trust to find healing from Jesus.

To understand the impact of this desired healing, one has to consider what healing implied in the ancient Mediterranean world - healing involved more than physical healing from a disease. Even today, healing implies the restoration of the total wellbeing of a person (Pilch 1988). This includes the restoration of meaning of life and honour. A healed person can again fully participate in societal activities. Healing therefore is culturally constructed. In this regard, one has to consider the difference between disease and illness. A disease causes sickness and is a pathological issue. Sickness exists irrespective of whether a culture recognises it or not. Sickness is caused by viruses and germs. Illness, on the other hand, refers to misfortunes in wellbeing beyond a pathological state. An ill person is a socially disvalued person. Restoring meaning of life for an ill person implies healing. The leper who approached Jesus had a disease that resulted in illness. He suffered a condition that was socially unacceptable. He was devalued and unwelcome in society. He was regarded as unclean and unholy. He had to live outside the community, as he could pollute the people of the community. The threat he posed for the community needed to be demonstrated and declared by his appearance and shouting (Lv 13:45). When Jesus healed him, he restored the leper's social stance and gave him new meaning in life.

Matthew's healing story is offered in the form of a striking parallelism. Verses 2 and 3 are similarly constructed:Participle + finite verb + saying + direct speech, which accentuate the interaction between the leper and Jesus. The interaction can be illustrated in a graphic manner (see Figure 2):

Jesus responds (Mt 8:3) to the approaching leper (Mt 8:2) - not by resenting him or scaring him away, but by stretching out his hand towards him. As the leper kneels before him, Jesus touches him. Instead of warning Jesus of his uncleanness, the leper makes a statement of faith and begs for healing. In response to the leper, Jesus answers that he is willing to heal the man, orders him to be healed and the man is healed.

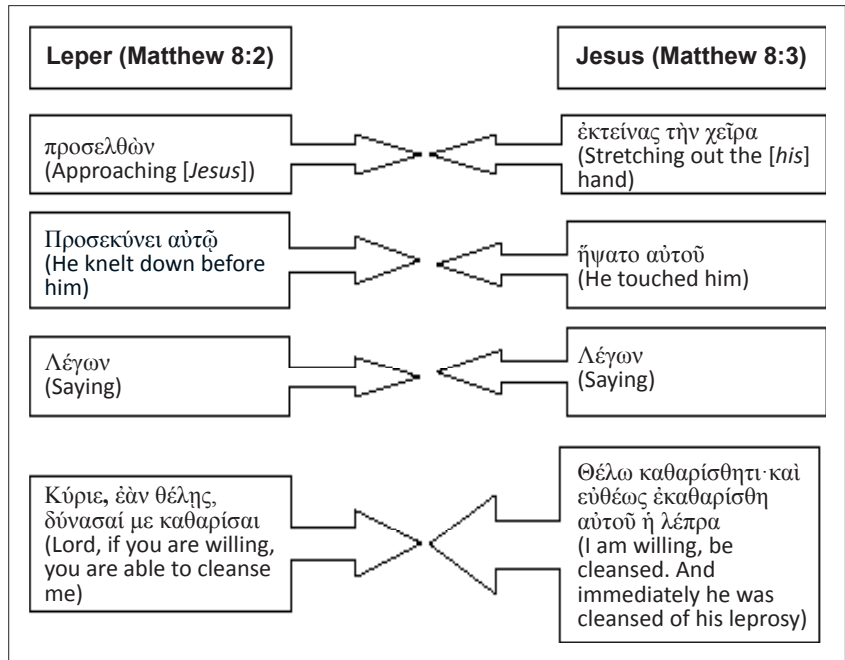

FIGURE 2: Interaction between Jesus and the leper. 
This brief pericope lacks the first and last elements of a full version of such a healing pericope (Hagner 1993:197) ${ }^{17}$ as no mention is made of the condition of the leper (first element) and no reaction of the onlookers (last element) is reported. All attention is focused on the interaction between the leper and Jesus.

Jesus' touching of the leper has special significance. As leprosy was regarded as an unclean disease, Jesus apparently was not supposed to come close to this man, let alone touch him. Neither Moses (Nm 12:9-15) nor Elisha (2 Ki 5:1-14) touched the leper they healed. Nevertheless, Jesus reaches out and touches this man to heal him and thereby seemingly violates the Levitical Law stated in Leviticus 5:3. ${ }^{18}$ The act of Jesus to touch the leper is all the

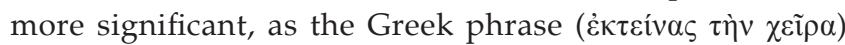
emphasises that Jesus reaches out to him. Furthermore, Jesus did not have to touch this man, as in some other healing stories Jesus healed people by speaking only. Osborne $(2010: 285,351)$ calls this act the 'love hermeneutic', that is the willingness to break Jewish taboos to help the suffering. Jesus is pictured as one whose concern for people apparently outweighs legal prescriptions.

A significant element of the act of touching should be considered. In the LXX, touching was a common gesture of a miracle healer in more than 80 occurrences (Luz 2001:6; Theissen 1983:62-63). Touching formed an important part of ancient healing stories. It was assumed that power and energy would flow from the holy person or healer to the ill one. When Jesus touched the leper, the leprosy and impurity did not spread to Jesus. Jesus is the Holy One and Healer. The power to heal and cleanse, flows from Jesus to the leper to conquer the disease. Leprosy is unable to affect Jesus. The word used for 'to heal' ( $\kappa \alpha \theta \alpha \rho i \sigma \alpha 1)$ proves the point. Illness with its devastating effects is cured, including uncleanness. Jesus, the Holy One, is the Saviour who achieves this.

Significantly, the story concludes with Jesus instructing the man to take his sacrifice and to show himself to the priests. It should be noted that the first and the second phases of the purification rituals, as prescribed in Leviticus 14:2-9, are left out. Jesus has already removed the impurity from the man (first phase of cleansing), and has already declared the man clean (second phase). What remains is the sacrifice of the third phase, so that the priest would allow him to be readmitted to the full communal and spiritual life. Jesus proves to have special power and authority. As Emmanuel, he is the Holy One. Purity flows from him to heal the infected person and he has the authority to declare the purity of the cleansed person. Jesus did not see any need to undergo any purification action for himself. The Gospels do not record that Jesus ever personally underwent any form of ritual purification. As the Holy One, he could not be defiled by touching the leper. Evans (2012:183) remarks that, instead of

17. Theissen (1983:72-80) identifies the various elements in miracles stories.

18.Chrysostom, in his homily on this passage, proposes that by this act, Jesus shows that he is set over the Law, and that, henceforth, to the clean nothing is unclean.
Jesus being defiled by the leper, 'purity flows from Jesus to the leper, healing the disease and restoring the man to a state of purity'.

The prescribed purification rites have been fulfilled. They pointed to Jesus. With his healing power, he assured that the true intention of the purity laws could be realised (Gundry 1982:138). The messianic times have arrived - times of health and the absence of all illness (Talbert 2010:112).

\section{Purity required of the followers of Jesus}

According to this healing narrative, it appears that ceremonial purity laws were no longer required in the Matthean community. The community accepted him as Emmanuel - the holy God amongst them. As Healer, he has come to save his people from their sins (Mt 1:21). He has purified and thus hallowed his followers. They now have to live as holy people. The concept of purity has been transposed from a cultic to an ethical level. In the Sermon on the Mount, Jesus demands pure hearts from his disciples: 'Blessed are the pure in heart, for they will see God' (Mt $5: 8)$. The phrase 'pure of heart' echoes the obligation described in Psalms 24:3-4: 'Who may ascend the mountain of the Lord? Who may stand in his holy place? The one who has clean hands and a pure heart.' A pure heart counters mere external ceremonial cleaning (cf. Mt 23:25-26). Pure hearts should mark the identity of Jesus' disciples. Their external behaviour should be based upon an internal ethical conviction.

\section{Conclusion}

This short story about Jesus who heals a leper describes another step in the coming of the Kingdom of God towards the paradisiac state pictured in Deutero-Isaiah. Jesus is in the process of establishing God's rule. He is described as a compassionate Healer and amazing miracle worker. Though it seems as if Jesus is violating the Law by touching the leper, the story actually demonstrates Jesus' healing power. Meaning of life is being restored for ill people. Whilst Jesus does not become impure when touching the leper, purity flows from him towards the leper. The purity laws find their fulfilment in him.

As the leper was purified, all Jesus' followers are purified. Boundaries of purity laws to categorise and isolate others are no longer applicable to them. Ritual purity becomes a moral category. Their inner beings, their hearts, must be pure. Purity involves integrity of the whole person.

\section{Acknowledgements Competing interests}

The author declares that he has no financial or personal relationship(s) that may have inappropriately influenced him in writing this article. 


\section{References}

Avi-Yonah, M., 2007, 'Second temple', in F. Skoling \& M. Berenbaum (eds.), Encyclopaedia Judaica, 2nd edn., vol. 19, pp. 608-611,Thompson Gale, Detroit/ New York/San Francisco/New Haven/Waterville/Maine/London.

Bowley, J.E., 2000, 'Purification texts', in C.A. Evans \& S.E. Porter (eds.), Dictionary of New Testament Background, pp. 873-874, InterVarsity Press, Downers Grove/ Leicester.

Carter, W., 2000, Matthew and the margins. A socio-political and religious reading, Academic Press, Sheffield. (Journal for the Study of the New Testament Supplement Series 204).

Chilton, B.D., 2000, 'Purity', in C.A. Evans \& S.E. Porter (eds.), Dictionary of New Testament Background, pp. 874-882, InterVarsity Press, Downers Grove/Leicester.

Davies, W.D. \& Allison D.C., 2004a, A critical and exegetical commentary on the Gospel according to Saint Matthew. (Matthew 1-7), vol. 1, T\&T Clark International, London/New York. (International Critical Commentary).

Davies, W.D. \& Allison D.C., 2004b, A critical and exegetical commentary on the Gospel according to Saint Matthew. (Matthew 8-18), vol. 2, T\&T Clark International, London/New York, (International Critical Commentary).

Deines, R., 2008, 'Not the Law but the Messiah: Law and righteousness in the Gospel of Matthew - An ongoing debate', in D.M. Gurtner \& J. Nolland (eds.), Built upon the Rock. Studies in the Gospel of Matthew, pp. 53-84, Eerdmans, Grand Rapids/ Cambridge.

Duling, D.C., 1992, 'Kingdom of God, Kingdom of heaven', in D.N. Freedman (ed.), The Anchor Bible Dictionary, vol. 4, pp. 56-69, Doubleday, New York/London/Toronto/ Sydney/Auckland.

Ellingworth, P., 1992, 'Leprosy', in J.B. Green \& S. McKnight (eds.), Dictionary of Jesus and the Gospels, pp. 463-464, InterVarsity Press, Downers Grove/Leicester.

Evans, C.A., 2012, Matthew, Cambridge University Press, Cambridge. (New Cambridge Bible Commentary).

Eisen, Y., 2004, Miraculous journey: A complete history of the Jewish people from creation to the present, Targum Press, Brooklyn.

Garland, D., 2001, Reading Matthew: A literary and theological commentary on the first Gospel, Smyth \& Helwys, Macon.

Grintz, Y.M., 2007, 'First Temple', in F. Skoling \& M. Berenbaum (eds.), Encyclopaedia Judaica, 2 nd edn., vol. 19, pp. 601-603, Thompson Gale, Detroit/New York/San Francisco/New Haven/Waterville/Maine/London.

Grundmann, W., 1971, Das Evangelium nach Matthäus. Theologischer Handkommentar zum Neuen Testament 1, Evangelische Verlagsanstalt, Berlin.

Gundry, R.H., 1982, Matthew: A commentary on his literary and theological art, Eerdmans, Grand Rapids.

Hagner, D.A., 1993, Matthew 1-13, Word Books, Dallas. (Word Biblical Commentary 33A).

Hagner, D.A., 1995, Matthew 14-28, Word Books, Dallas. (Word Biblical Commentary 33B.).
Hayes, C., 2007, 'Purity and impurity, ritual', in F. Skoling \& M. Berenbaum (eds.), Encyclopaedia Judaica, 2nd edn., vol. 16, pp. 746-756, Thompson Gale, Detroit/New York/San Francisco/New Haven/Waterville/Maine/London.

Hübner, H., 1992, 'Unclean and clean (New Testament)', in D.N. Freedman (ed.), The Anchor Bible Dictionary, pp. 741-745, Doubleday, New York/London/Toronto/ Sydney/Auckland.

Klostermann, E., 1927, Das Mattäusevangelium. Handbuch zum Neuen Testament, Mohr, Tübingen.

Luz, U., 2001, Matthew 8-20: A commentary, Fortress Press, Minneapolis.

Marshall, I.H., 1978, Commentary on Luke, Eerdmans, Grand Rapids. (The New International Greek Testament Commentary).

Morris, L., 1992, The Gospel according to Matthew, William Eerdmans, Grand Rapids/ Leicester.

Osborne, G.R., 2010, Matthew, Zondervan, Grand Rapids. (Zondervan Exegetical Commentary On The New Testament).

Pilch, J.J., 1981, 'Biblical leprosy and body symbolism', Biblical Theology Bulletin 11, 108113. http://dx.doi.org/10.1177/014610798101100403

Pilch, J.J., 1988, 'Understanding Biblical healing: Selecting the appropriate model', Biblical Theological Bulletin 18, 60-66. http://dx.doi.org/10.1177/014610798801800204

Pilch, J.J. \& Malina, B.J., 1998, Handbook of Biblical social values, Hendrickson Publishers, Peabody.

Roth, S.J., 1994, The blind, the lame and the poor: Character types in Luke-Acts, Academic Press, Sheffield. (Journal for the Study of the New Testament Supplement Series 144).

Senior, D., 1998, Matthew, Abingdon Press, Nashville. (Abingdon New Testament Commentaries).

Talbert, C.H., 2010, Matthew, Baker Academic, Grand Rapids. (Paideia Commentaries on the New Testament).

Theissen, G., 1983, The miracle stories of the early Christian tradition, Fortress Press, Philadelphia.

Viljoen, F.P., 2013, 'Jesus' halakhic argumentation on the true intention of the law in Matthew 5:21-48', Verbum et Ecclesia 34(1), Art. \#787, 12 pages.

Westerholm, S., 1992, 'Clean and unclean', in J.B. Green \& S. McKnight (eds.), Dictionary of Jesus and the Gospels, pp. 125-132, InterVarsity Press, Downers Grove/Leicester.

Witherington, B., 2006, Matthew, Smyth \& Helwys Bible Commentary, vol. 19, Smyth \& Helwys Publishing, Macon.

Wright, D.P., 1992a, 'Holiness (Old Testament)', in D.N. Freedman (ed.), The Anchor Bible Dictionary, vol. 3, pp. 237-249, Doubleday, New York/London/Toronto/Sydney/ Auckland.

Wright, D.P., 1992b, 'Unclean and clean (Old Testament)', in D.N. Freedman (ed.), The Anchor Bible Dictionary, vol. 5, pp. 729-741, Doubleday, New York/London/Toronto/ Sydney/Auckland.

Wright, D.P. \& Jones, R.N., 1992, 'Leprosy', in D.N. Freedman (ed.), The Anchor Bible Dictionary, vol. 4, pp. 277-282, Doubleday, New York/London/Toronto/Sydney/ Auckland. 